\title{
Mutồwĝ̀sith
}

\begin{tabular}{|l|c|c|}
\cline { 2 - 3 } \multicolumn{1}{c}{ JURNAL } & HUKUM & ISLAM \\
\hline Vol. 4. No. 2 (2021) 75-88 & E-ISSN: : 2723-4681 & P-ISSN: 2722-2764 \\
\hline \multicolumn{2}{|c|}{ Published online on the journal's website: } \\
http://jurnal.iailm.ac.id/index.php/mutawasith \\
\hline
\end{tabular}

\section{Penanganan Perkara Permohonan Itsbat Nikah Poligami Secara Siri Berdasarkan Surat Edaran Mahkamah Agung Nomor 3 Tahun 2018}

\author{
Muhammad Ihsan Fauzi \\ Mahasiswa Pascasarjana UIN Sunan Gunung Djati Bandung \\ Ihsanfauzi@gmail.com
}

\begin{tabular}{|c|c|c|}
\hline Received: & Revised: & Published: \\
\hline 03-09-2021 & 22-11-2021 & 25-12-2021 \\
\hline \multicolumn{2}{|c|}{ DOI: https://doi.org/ 10.47971/mjhi.v4i2.339 } \\
\hline
\end{tabular}

\begin{abstract}
Abstrak
Tujuan penelitian ini adalah untuk menganalisis penanganan perkara permohonan itsbat nikah poligami secara siri berdasarkan Sema Nomor 3 tahun 2018. Secara teoritis, penelitian ini diharapkan dapat menghasilkan atau memberikan manfaat sebagai sumbangan pemikiran bagi dunia hukum, khususnya di bidang Peradilan Agama sedangkan secara peraktis, dapat menjadi pertimbangan untuk diterapkan dalam dunia peradilan sebagai solusi terhadap permasalahan yang sama. Penelitian ini menggunakan pendekatan yuridis normatif dan deskriptif analitis dan wawancara kepada hakim sebagai pelaksana tugas yudisial. Hasil penelitian ini menunjukan bahwa SEMA berkedudukan di bawah undang-undang, bukan setara atau lebih tinggi dari undang-undang. Oleh karena itu hakim boleh mengesampingkan SEMA. Jika MA hendak membuat peraturan yang materinya berupa hukum acara peradilan sebaiknya bentuk produk hukumnya peraturan, setidak-tidaknya berbentuk PERMA.
\end{abstract}

kata kunci: Itsbat, nikah, poligami, Mahkamah Agung

\section{Abstract}

The purpose of this study is to analyze the handling of polygamous marriage application cases in a series based on Sema Number 3 of 2018. Theoretically, this research is expected to produce or provide benefits as a contribution of thought to the world of law, especially in the field of Religious Justice while in the field of religious justice while in accounting, it can be considered to be applied in the world of justice as a solution to the same problem. L'étude utilise une approche juridique normative et descriptive analytique et interroge les juges en tant qu'exécuteurs testamentaires des fonctions judiciaires. Les résultats de cette étude montrent que la SEMA est domiciliée en vertu de la loi, pas équivalente ou supérieure à la loi. Par conséquent, le juge peut renoncer à la SEMA. Si l'AM veut faire des règlements dont le matériel est sous la forme d'un droit de l'événement judiciaire devrait former des règlements de produits légaux, au moins sous la forme de PERMA. Key words: itsbat, marriage, polygamy, supreme court

\section{A. PENDAHULUAN}

Perubahan kondisi menuntut kemampuan Badan peradilan dalam menangkap fenomena-fenomena perubahan, menganalisa dampaknya, dan menyiapkan langkah- 
langkah guna menghadapi kondisi yang mengharuskan Badan Peradilan untuk secara cepat menyesuaikan dengan perkembangan zaman. Perubahan kondisi seperti saat ini yang sedang dihadapi oleh Badan Peradilan, banyaknya permasalahan timbul akibat adanya perubahan kondisi diharapkan Badan Peradilan memberikan pelayanan hukum yang berkeadilan kepada para pencari keadilan. Keadilan bagi para pencari keadilan pada dasarnya merupakan suatu nilai yang subyektif, karena adil menurut satu pihak belum tentu adil bagi pihak lain.

Pengadilan Agama adalah salah satu dari empat lingkungan peradilan yang dibawahi Mahkamah Agung dan sebagai salah satu Peradilan di Indonesia yang bersifat khusus, dua peradilan khusus lainnya adalah Peradilan Militer dan Peradilan Tata Usaha Negara. Pengadilan Agama berwenang dalam perkara perdata tertentu dan diberi wewenang oleh peraturan perundang-undangan negara untuk mewujudkan hukum material Islam dan batas-batas kekuasaannya.

Setelah ditetapkannya Undang-Undang Nomor 3 Tahun 2006 tentang Perubahan atas Undang-Undang Nomor 7 Tahun 1989 tentang Peradilan Agama, ketentuan Pasal 49 diubah sehingga ketentuan Pasal 49 mengatur bahwa Pengadilan Agama bertugas serta berwenang memeriksa, memutus, dan menyelesaikan perkara ditingkat pertama antara orang-orang yang beragama Islam. ${ }^{1}$ Salah satunya di bidang Perkawinan. Masalah hukum perkawinan yang berhubungan dengan Peraturan Perundang-Undangan tentang Peradilan agama, antara lain Itsbat nikah. Itsbat nikah mengandung makna penetapan perkawinan melalui pencatatan perkawinan oleh pejabat yang berwenang berdasarkan Peraturan Perundang-Undangan. ${ }^{2}$

Penetapan perkawinan (Itsbat nikah) juga dapat dilakukan oleh Pengadilan Agama sebagaimana diatur dalam Pasal 34 poin (a) Undang-Undang Nomor 23 Tahun 2006 tentang Administrasi Kependudukan yang menyatakan "Bagi yang beragama Islam, penetapan perkawinan (Itsbat nikah) dilakukan oleh Pengadilan Agama setempat sesuai dengan domisili (wilayah hukum) yang bersangkutan". Itsbat menjadi salah satu kewenangan Pengadilan agama berdasarkan Instruksi Presiden (Inpres) No. 1 Tahun 1991 tentang KHI Pasal 7 dan Penjelasan Pasal 49 Undang-Undang Nomor 7 Tahun 1987 Jo. Undang-Undang Nomor 3 Tahun 2006 Jo Nomor 50 Tahun 2009. Namun dalam hal itsbat terdapat beberapa permasalahan yaitu ketika pelaksanaan itsbat, ternyata salah satu pasangan nikah sirinya masih terikat dalam perkawinan sebelumnya yang sah. ${ }^{3}$ Dalam hal ini penulis melihat ada penyelundupan hukum yaitu poligami tanpa prosedur berbalut izin itsbat nikah/penetapan perkawinan.

Peraturan Mahakamah Agung (PERMA), Fatwa, Surat Keputusan Ketua Mahkamah Agung (SK KMA) dan Surat Edaran Mahkamah Agung (SEMA) Henry P. Panggabean dalam

${ }^{1}$ Aden Rosyadi, Peradilan Agama di Indonesia, (Bandung: Simbiosa, 2015), hlm. 12

${ }^{2}$ Ibid.

${ }^{3}$ Mukhtar Zamzami, Perempuan dan Keadilan Dalam Hukum Kewarisan Indonesia, (Jakarta: Prenada Media, 2013), hlm. 113. 
bukunya "Fungsi Mahkamah Agung dalam Praktik Sehari-Hari" mengatakan "Peraturan MA pada dasarnya adalah bentuk peraturan yang berisi ketentuan bersifat hukum acara dan SEMA edaran pimpinan MA keseluruh jajaran peradilan yang berisi bimbingan dalam penyelenggaraan peradilan dan bersifat administrasi. ${ }^{4 \prime}$

Berdasarkan Surat Edaran Mahkamah Agung (SEMA) Nomor 3 Tahun 2018 angka 8, MA mengeluarkan hasil Rumusan Hukum dari Rapat Pleno Kamar Agama yang isinya bahwa permohonan itsbat nikah poligami atas dasar nikah siri itu jelas tidak boleh dilaksanakan.

"Permohonan itsbat nikah poligami atas dasar nikah siri meskipun dengan alasan untuk kepentingan anak harus dinyatakan tidak dapat diterima. Untuk menjamin kepentingan anak dapat diajukan permohonan asal-usul anak"

Namun demikian dalam pelaksanaannya tidak semua ketentuan dalam SEMA tersebut dilaksanakan sepenuhnya oleh Majelis Hakim di pengadilan tingkat pertama, seperti pada fakta putusan hakim Pengadilan Agama Bandung menerima dan mengabulkan permohonan itsbat nikah poligami dan mengesampingkan larangan yang telah diatur dalam SEMA Nomor 3 tersebut diatas, karena beberapa pertimbangan sebagaimana yang terdapat dalam Penetapan Itsbat Nikah No. 202/Pdt.P/2019/PA. Badg pasca diterbitkannya SEMA No. 3 Tahun 2018 yang pada pokoknya menetapkan:

1) mengabulkan permohonan Pemohon I dan Pemohon II;

2) menyatakan sah perkawinan antara Pemohon I (Wawan Dermawan bin Muhamad) dengan Pemohon II (Elly Walyah binti Endang) yang dilaksanakan pada tanggal 03 Juni 2016 dalam wilayah Kecamatan Andir, Kota Bandung;

3) Membebankan biaya perkara kepada Pemohon I dan Pemohon II sejumlah Rp. 296.000 (dua ratus Sembilan puluh enam ribu rupiah)

Demikian juga ada beberapa Putusan Pengadilan Agama pasca diterbitkannya SEMA ini yang tidak menerima dan tidak mengabulkan permohonan itsbat nikah poligami, dengan demikian penulis melihat ada permasalahan hukum. Oleh karena itu hal ini perlu diteliti lebih lanjut terkait penanganan perkara permohonan itsbat nikah poligami secara siri berdasarkan Sema Nomor 3 Tahun 2018 untuk kepastian hukumnya.

\section{B. METODE}

Penelitian ini menggunakan pendeketan yuridis normatif dan deskriptif analitis dan wawancara kepada hakim sebagai pelaksana tugas yudisial. Penelitian dilakukan oleh penulis dengan menguraikan fakta yang ada dan mendeskripsikan sebuah masalah yang mengarah kepada penemuan hukum pada produk pengadilan dan menjadikan asumsi dikalangan akademisi bahwa hakim di Indonesia sudah banyak yang memperkaya putusannya dengan sumber hukum lain seperti ijtihad hakim, yurisprudensi dan doktrin.

${ }^{4}$ Panggabean Henry P, Fungsi Mahkamah Agung dalam Praktik Sehari-Hari, (Jakarta: Sinar Harapan, 2001), hlm. 104. 
Analisis ini secara umum diartikan sebagai metode yang meliputi semua analisis teks tetapi disisi lain analisis isi juga digunakan untuk mendeskripsikan pendekatan analisis yang khusus. Dalam analisis putusan ini menitikberatkan kepada metode penafsiran putusan hakim (penafsiran sistematikal) melalui Undang-Undang atau PasalPasalnya dengan melihat perkembangan terjadinya putusan mulai dari proses yang melatar belakangi hakim menerapkan hukum pada putusan tersebut, disamping itu menurut Surjono Sukanto penelitian hukum memuat sumber data primer yang langsung diperoleh dari prilaku dan/atau masyarakat. ${ }^{5}$

\section{HASIL PENELITIAN DAN PEMBAHASAN}

SEMA Nomor 3 Tahun 1963 pada dasarnya tidak memiliki kekuatan untuk mengubah atau membatalkan undang-undang, seperti KUH Perdata. Dengan demikian, Pasal 1238 KUH Perdata tetap berlaku dan memiliki kekuatan hukum mengikat. Hal ini di dukung dengan pernyataan hasil dari wawancara antara penulis dengan Hakim pada Pengadilan Agama Bandung "Drs. H. Badrudin., M.H” yang menyatakan bahwa, "SEMA bukan peraturan perundang-undangan, secara norma hukum hakim boleh contra legem dengan SEMA karena SEMA tidak mengikat maka sebagai hakim boleh mengesampingkan. Tidak dipungkiri juga ada kekhawatiran-khawatiran pada diri seorang hakim untuk contra legem dengan SEMA yang sudah disepakati pada rapat pleno, karena bagaimanapun yang membuat SEMA adalah atasan dari hakim itu sendiri. ${ }^{\prime \prime}$

Pasal 24 A Undang-Undang Dasar RI 1945 mengatur MA berwenang mengadili pada tingkat kasasi, menguji peraturan perundang-undangan di bawah undang-undang terhadap undang-undang, dan mempunyai wewenang lainnya yang diberikan undangundang. Hal Ini sejalan dengan pandangan penulis bahwa, peraturan perundangundangan hanya dapat dibentuk oleh lembaga-lembaga yang memperoleh kewenangan perundang-undangan (wetgevings bevoegheid) (Soeprapto., 1998), yaitu kekuasaan untuk membentuk hukum atau rechtsvorming.

Undang-Undang yang mengatur Mahkamah Agung, mulai dari Undang-Undang Nomor 14 Tahun 1985, hingga dua kali perubahannya yakni Undang-Undang Nomor 5 Tahun 2004, dan Undang-Undang Nomor 3 Tahun 2009 (selanjutnya disebut UUMA). Ada beberapa kewenangan dan tugas yang diberikan Undang-Undang kepada MA, antara lain:

1) MA memberikan pertimbangan hukum kepada Presiden dalam permohonan grasi dan rehabilitasi (Pasal 14 ayat 1 UUD jo Pasal 35 UUMA);

2) MA dapat memberikan pertimbangan-pertimbangan dalam bidang hukum baik diminta maupun tidak kepada lembaga tinggi negara yang lain (Pasal 37 UUMA).

3) MA berwenang memberikan petunjuk di semua lingkungan peradilan dalam rangka pelaksanaan ketentuan UU Kekuasaan Kehakiman (Pasal 38 UUMA).

\footnotetext{
${ }^{5}$ Soekanto Soejono, Pengantar Penelitian Hukum, (Jakarta: Ul-Press, 2005), hlm. 211.

${ }^{6}$ Wawancara dengan Bapak Drs. H. Badrudin. M.H, pada tanggal 04 Maret 2021
} 
4) MA berwenang memberikan petunjuk, teguran, atau peringatan yang dipandang perlu kepada pengadilan di semua lingkungan peradilan.

Dalam literatur kewenangan dan tugas demikian disebut sebagai fungsi pengaturan atau regelende functie MA. Ini juga sejalan dengan rumusan Pasal 79 UUMA, yang mengatur: "MA dapat mengatur lebih lanjut hal-hal yang diperlukan bagi kelancaran penyelenggaraan peradilan apabila terdapat hal-hal yang belum cukup diatur dalam Undang-Undang ini"7 (Panggabean Henry P, 2001).

Peraturan MA atau PERMA pada dasarnya adalah bentuk peraturan yang berisi ketentuan bersifat hukum acara. Sedangkan, Surat Edaran MA atau SEMA bentuk edaran pimpinan MA ke seluruh jajaran peradilan yang berisi bimbingan dalam penyelenggaraan peradilan, yang lebih bersifat administrasi. Fatwa MA berisi pendapat hukum MA yang diberikan atas permintaan lembaga negara. Surat Keputusan Ketua MA atau SK KMA adalah surat keputusan (beschikking) yang dikeluarkan Ketua MA mengenai satu hal tertentu.

Merujuk pada Undang-Undang No. 10 Tahun 2004 tentang Pembentukan Peraturan Perundang-Undangan Nomor 10 Tahun 2004), yang telah diganti dengan Undang-Undang No. 12 Tahun 2011 tentang Pembentukan Peraturan Perundang-Undangan. Pada Pasal 8 ayat (1) Undang-Undang Nomor 12 Tahun 2011 mengatur:

"Jenis Peraturan Perundang-undangan selain sebagaimana dimaksud dalam Pasal 7 ayat (1) mencakup peraturan yang ditetapkan oleh Majelis Permusyawaratan Rakyat, Dewan Perwakilan Rakyat, Dewan Perwakilan Daerah, Mahkamah Agung, Mahkamah Konstitusi, Badan Pemeriksa Keuangan, Komisi Yudisial, Bank Indonesia, Menteri, badan, lembaga, atau komisi yang setingkat yang dibentuk dengan Undang-Undang atau Pemerintah atas perintah Undang-Undang, Dewan Perwakilan Rakyat Daerah Provinsi, Gubernur, Dewan Perwakilan Rakyat Daerah Kabupaten/Kota, Bupati/Walikota, Kepala Desa atau yang setingkat."

Rumusan ini senafas dengan Pasal 7 ayat (4) dan penjelasan Undang-Undang Nomor 10 Tahun 2004. Selanjutnya Pasal 8 ayat (2) Undang-Undang Nomor 12 Tahun 2011 menegaskan peraturan perundang-undangan tersebut diakui keberadaannya dan mempunyai kekuatan hukum mengikat sepanjang diperintahkan oleh peraturan perundang-undangan yang lebih tinggi atau dibentuk berdasarkan kewenangan.

Kasus posisi ini tentang persoalan itsbat nikah dalam perkara perkawinan yang dilaksanakan menurut hukum Islam terdapat dalam putusan dengan nomor putusan 202/Pdt.P/2019/PA.Badg yang telah diputuskan di Pengadilan Agama Bandung pada tanggal 30 april 2019 bertepatan dengan tanggal 25 Sya'ban 1440 Hijriah.

Perkara ini terjadi antara Pemohon I (Fulan bin Fulan) berstatus duda cerai dengan seorang perempuan yaitu Pemohon II (Fulanah binti Fulan) berstatus janda cerai. Pemohon I berusia 39 Tahun dan Pemohon II yang berusia 33 Tahun, Agama Islam,

\footnotetext{
${ }^{7}$ Panggabean Henry P, op. cit., hlm. 35.
} 
pekerjaan Pemohon I adalah karyawan swasta sedangankan Pemohon II adalah Ibu Rumah Tangga. Bertempat tinggal di jalan Ciroyom Kelurahan Dungus Cariang Kecamatan Andir, Kota Bandung.

Sebagaimana disebutkan teori sistem peradilan di Indonesia perkara itsbat nikah ini karena para pihak berada di yurisdiksi Pengadilan Agama Bandung maka permohonan diajukan ke Pengadilan Agama Bandung sebagai pengadilan yang berwenang memeriksa, mengadili dan memutuskan perkara terebut di atas. Bahwa maksud dan tujuan permohonan Pemohon I dan Pemohon II adalah sebagaimana diuraikan di atas, maka majelis hakim menimbang:

Bahwa pada tanggal 12 April 2010 yang menjadi alasan diajukannya permohonan Pengesahan Nikah ini karena pernikahan antara Pemohon I dengan Pemohon II tidak tercatat di Kantor Urusan Agama Kecamatan Cibeunying Kidul Kota Bandung, oleh karena itu Pemohon I dan Pemohon II memohon agar Pengadilan Agama Bandung menetapkan perkawinan antara Pemohon I dengan Pemohon II yang dilangsungkan di wilayah Kantor Urusan Agama Kecamatan Ciebunying Kidul Kota Bandung adalah sah.

Dari dalil permohonan Pemohon I dan Pemohon II dan dihubungkan dengan alat bukti, baik surat maupun saksi HS bin RO dan $\mathrm{Hr}$ H bin AS serta sumpah Pemohon I dan Pemohon II di depan persidangan, diperoleh fakta sebagai berikut:

1) Pada tanggal 12 April 2010 telah terjadi pernikahan menurut hukum agama Islam antara Pemohon I dengan Pemohon II yang dilangsungkan di wilayah Kantor Urusan Agama Kecamatan Cibeunying Kidul Kota Bandung;

2) Bahwa pernikahan antara Pemohon I dengan Pemohon II telah memenuhi syarat dan rukun nikah sebagaimana ketentuan hukum Islam;

3) Bahwa pada waktu nikah, Pemohon I berstatus duda cerai dan Pemohon II berstatus perawan, dari pernikahan mereka tersebut telah dikaruniai 1 (satu) orang anak;

4) Bahwa perkawinan antara Pemohon I dengan Pemohon II tidak tercatat di wilayah Kantor Urusan Agama Kecamatan Cibeunying Kidul Kota Bandung, oleh karena itu Pemohon I dan Pemohon II memohon agar Pengadilan Agama Bandung menetapkan perkawinan antara Pemohon I dengan Pemohon II yang dilangsungkan di wilayah Kantor Urusan Agama Kecamatan Cibeunying Kidul Kota Bandung pada tanggal 12 April 2010 adalah sah;

5) Bahwa Penetapan Pengadilan Agama Bandung akan digunakan oleh Pemohon I dan Pemohon II untuk mengurus kutipan akta nikah, akte kelahiran anak mereka dan untuk kepentingan hukum lainnya;

Berdasarkan pertimbangan tersebut, Pengadilan menilai bahwa Pemohon I dan Pemohon II telah dapat membuktikan dalil permohonannya yaitu bahwa perkawinan Pemohon I dan Pemohon II telah dilaksanakan sesuai dengan agama Islam; 
Sesuai dengan ketentuan Pasal 2 ayat (1) Undang-undang Nomor 1 tahun 1974 tentang perkawinan, maka pernikahan Pemohon I dan Pemohon II yang dilaksanakan pada tanggal 12 April 2010 di wilayah Kantor Urusan Agama Kecamatan Cibeunying Kidul Kota Bandung adalah sah;

Menimbang, bahwa hal lain yang tidak dipertimbangkan seperti petitum permohonan angka 3, harus dianggap dikesampingkan;

Menimbang, bahwa perkara ini termasuk bidang perkawinan, sesuai Pasal 89 ayat (1) Undang-Undang Nomor 7 Tahun 1989 jo. Pasal 90 Undang-Undang Nomor 3 Tahun 2006, maka biaya yang timbul dalam perkara ini harus dibebankan kepada Pemohon I dan Pemohon II;

Memperhatikan segala ketentuan hukum yang berlaku dan berkaitan dengan perkara tersebut Majelis Hakim Pengadilan Agma Bandung menetapkan pertama mengabulkan permohonan Pemohon I dan Pemohon II, kedua Majelis Hakim Pengadilan Agma Bandung menyatakan sah perkawinan antara Pemohon I (Fulan bin Fulan) dengan Pemohon II (Fulanah binti Fulan) yang dilaksanakan pada tanggal 03 Juni 2016 di wilayah Kantor Urusan Agama Kecamatan Andir Kota Bandung, dan ketiga membebankan biaya perkara kepada Pemohon I dan Pemohon II.

Dalam kasus ini penulis melakukan analisis yang dapat memberikan penjelasan lebih mendalam lagi tentang pertimbangan hakim dalam menerima, memutus dan menyelesaikan perkara itsbat nikah poligami. Dalam kasus ini Pemohon berstatus duda cerai dan janda cerai. Perkawinan keduanya telah dilangsungkan di wilayah KUA Kecamatan Cibeunying Kidul Kota Bandung namun tidak tercatat di KUA setempat dan mengajukan permohonan itsbat nikah untuk melegalkan pernikaahannya tersebut karena ada kepentingan diantaranya untuk mendapatkan buku nikah, kartu keluarga, dan untuk pendidikan anak yang lahir semasa pernikahan.

Dalam SEMA Nomor 3 Tahun 2018 tentang Permohonan Itsbat Nikah Poligami Atas Dasar Nikah Siri, menyebutkan bahwa:

"Permohonan itsbat nikah poligami atas dasar nikah siri meskipun dengan alasan untuk kepentingan anak harus dinyatakan tidak dapat diterima. Untuk menjamin kepentingan anak dapat diajukan permohonan asal-usul anak" (SEMA Nomor 3 Tahun 2018, 2018).

Pasal ini mengandung asas bahwa suatu permohonan itsbat nikah poligami yang diajukan ke Pengadilan Agama harus diputus niet ontvankelijke verklaard (N.O) putusan yang menyatakan bahwa permohonan tidak dapat diterima. Disini dapat dilihat adanya penundukan hakim terhadap SEMA suatu peraturan yang diberlakukan oleh Mahkmah Agung (MA) dari hasil rapat pleno kamar agama pada 16 November 2018 yang dalam hierarkinya SEMA tidak berada diatas atau setara peraturan perundang-undangan, di Indonesia sendiri sebagaimana tercantum dalam teori Penegakan Hukum di Indonesia Pasal 1 Ayat (1) Undang-Undang Nomor 48 Tahun 2009 memberikan definisi bahwa, kekuasaan kehakiman adalah kekuasaan negara yang merdeka untuk menyelenggarakan 
peradilan guna menegakan hukum dan keadilan berdasarkan Pancasila, hal ini menunjukan Hakim masih dipaksa tunduk terhadap atasannya.

Sedangkan sistem peradilan di Indonesia menganut asas Ius Curia Novita atau Ius Novit Jus bahwa setiap hakim dianggap tahu akan hukumnya dalam memberikan putusan berdasarkan keilmuan yang dimilikinya pendapat ini dikemukakan juga oleh Yahya Harahap berdasarkan adagium Ius Curia Novita tau Curia Novit Jus, seorang hakim dianggap mengetahui dan memahami segala persoalan hukum. Oleh karena itu maka hakim yang berwenang menentukan hukum objektif mana yang harus diterapkan (toepassing) dalam konstruksi putusannya sesuai dengan materi pokok perkara antara pihak-pihak yang berperkara dalam menyangkut hubungan hukum konkreto. ${ }^{8}$

Mengacu kepada Undang-Undang tentang Kekuasaan Kehakiman yang saat ini berlaku adalah Undang-Undang Nomor 48 tahun 2009 tentang Kekuasaan Kehakiman yang mana Undang-Undang Nomor 48 Tahun 2009 mencabut Undang-Undang Nomor 4 Tahun 2004 tentang Kekuasaan Kehakiman karena dianggap tidak sesuai lagi dengan kebutuhan hukum dan ketatanegaraan menurut UUD NRI 1945. Maka bisa dianggap jika seorang hakim memutus perkara Itsbat Nikah Poligami contra legem kepada SEMA Nomor 3 Tahun 2018, Hakim menganggap SEMA itu sudah tidak sesuai dengan keadaan masyarakat atau menurut nurani seorang hakim peraturan tersebut dirasa kurang adil diterapkan kepada pihak yang berperkara itu dengan mengacu kepada fakta yang terjadi saat pemeriksaan.

Sunario, Wakil Ketua Mahkamah Agung RI Bidang Non Yudisial menyampaikan pandangannya saat memberi pembinaan pada acara Pembinaan Teknis Peradilan Agama Virtual: Batas Kewenangan Mahkamah Agung dan Komisis Yudisial Dalam Mengawasi Hakim bahwa hakim di lingkungan peradilan agama tidak wajib dibina kembali karena statusnya sudah layak dan pantas untuk menjadi Pembina. Menurutnya sudut pandang kewenangan dan bidang pengawasan terkait dengan beberapa isu dimasyarakat yang bermunculan dalam hal batas kewenangan. Menurut Sunario kemerdekaan, independensi dan kemandirian memiliki makna yang sama hanya berbeda pada pemilihan diksi, karena visi MA sendiri adalah menjaga kemandirian badan peradilan. ${ }^{9}$

Timbul pertanyaan mengapa kemandirian hakim harus diganggu dengan mengambil tindakan-tindakan yang dapat mencederai kemandirian atau independensi hakim. Kemandirian hakim juga tidak lepas dari tanggung jawabnya, Sunario memaparkan beberapa batasan dan cakupan kemandirian kekuasaan kehakiman di Indonesia, yaitu:

1) Substantif Independen (independent dalam memutus perkara)

2) Personal Independen (meliputi jaminan masa kerja dan jabatan)

\footnotetext{
${ }^{8}$ Yahya Harahap, Hukum Acara Perdata tentang Gugatan, Persidangan, Penyitaan, Pembuktian dan Putusan Pengadilan, (Jakarta: Sinar Grafika, 2016), hlm. 98.

9 Webinar berjudul Optimalisasi Peran dan Fungsi Pengadilan Agama dalam Perkawinan. Dilaksanakan pada tanggal 23 Agustus 2021.
} 
3) Internal Independen (independent dari atasan dan rekan kerja)

Independensi Hakim bukan menjadi pembicaraan baru, tetapi sudah dimulai sejak Tahun 1999 setelah revormasi birokrasi bergulir dan sudah diatur oleh Undang-Undang Nomor 35 Tahun 1999 perubahan atas Undang-Undang Nomor 14 Tahun 1970 buah revormasi penghapusan campur tangan eksekutif terhadap yudikatif (Sunario, 2021). Bab IX Pasal 24 Undang-Undang Dasar 1945 menyatakan: ${ }^{10}$

"Kekuasaan kehakiman merupakan kekuasaan yang merdeka untuk menyelenggarakan peradilan guna menegakan hukum dan keadilan."

Pengawasan yang dilakukan oleh Mahkamah Agung dan Komisi Yudisial tidak boleh dimaknai sebagai upaya yang dapat mengganggu independensi tersebut, sehingga Mahkamah Agung dan Komisi Yudisial diamanatkan oleh undang-undang untuk membuat kode etik hakim dan perilaku hakim.

Mahkamah Agung diberi amanat oleh undang-undang sebagai pengawas tertinggi terhadap penegakan peradilan sebagai konsekuensi Undang-Undang Nomor 35 Tahun 1999 sebagai pengawas tertinggi. MA dalam peranan pengawasannya tidak boleh terburu-buru dalam arti begitu ada ada isu secara sepontan dan seketika mengambil tindakan karena MA harus mempertimbangkan kata independensi tadi (Sunario, 2021).

Dari beberapa pendapat yang dikemukakan oleh para ahli dan praktisi diatas diketahui sebaiknya ukuran yang dipakai baik undang-undang atau peraturan lainnya jangan sampai sebuah produk hukum itu mengurangi kebebasan hakim dalam memeriksa dan memutus suatu perkara.

Dalam pertimbangan hakim pada Putusan Nomor 202/Pdt.P/2019/PA.Badg majelis hakim menimbang, bahwa yang menjadi alasan diajukannya permohonan Pengesahan Nikah ini karena pernikahan antara Pemohon I dengan Pemohon II tidak tercatat di Kantor Urusan Agama Kecamatan Ciebunying Kidul Kota Bandung, oleh karena itu Pemohon I dan Pemohon II memohon agar Pengadilan Agama Bandung menetapkan perkawinan antara Pemohon I dengan Pemohon II yang dilangsungkan di wilayah Kantor Urusan Agama Kecamatan Cibeunying Kidul Kota Bandung pada tanggal 12 April 2010 adalah sah.

Sesuai dengan Hukum Acara Perdata di Pengadilan Agama bahwa pada Bab I Pasal 2 Jo. Pasal 49 Undang-Undang Nomor 7 Tahun 1989 Jo. Pasal 49 Undang-Undang Nomor 3 Tahun 2006 tentang Perubahan atas Undang-Undang Nomor 7 Tahun 1989 tentang Peradilan Agama ditetapkan tugas dan kewenangannya yaitu memeriksa, memutusa dan menyelesaikan perkara-perkara di bidang perdata salah satunya dibidang perkawinan (Sulaikin. Lubis, 2006). ${ }^{11}$

Tugas pokok hakim adalah menerima, memeriksa dan mengadili serta menyelesaikan perkara yang diajukan ke Pengadilan Agama, dalam hal ini hakim tidak

\footnotetext{
10 Sunario, Hasil webinar tentang Pembinaan Teknis Peradilan Agama Virtual: Batas Kewenangan Mahkamah Agung dan Komisi Yudisial dalam Mengawasi Hakim. Dilaksanakan pada tanggal 16 Juli 2021.

${ }^{11}$ Sulaikin Lubis, Hukum Acara Perdata Peradilan Agama di Indonesia, (Jakarta: Kencana, 2006), hlm. 17.
} 
boleh memihak dalam menyelesaikan perkara yang diformulasikan dalam teks putusan. Bagi hakim dalam memeriksa dan mengadili suatu perkara yang terpenting adalah fakta atau peristiwanya bukan hukumnya saja, karena peraturan atau hukum adalah sebuah alat sedangkan yang menentukan pada produk pengadilan adalah putusan hakim sesuai fakta yang konkrit. Hal ini sesuai dengan Undang-Undang Nomor 7 Tahun Tahun 1989 yang telah diamandemen dengan Undang-Undang Nomor 3 Tahun 2006.

Dalam pertimbangan yang selanjutnya majelis hakim menimbang, bahwa dari dalil permohonan Pemohon I dan Pemohon II dan dihubungkan dengan alat bukti, baik surat maupun saksi HS bin RO dan Hr H bin AS serta sumpah Pemohon I dan Pemohon II di depan persidangan, diperoleh fakta dari keterangan saksi. Bahwa setelah mendengar keterangan dari saksi, Pengadilan menilai bahwa Pemohon I dan Pemohon II telah dapat membuktikan dalil permohonannya yaitu bahwa perkawinan Pemohon I dan Pemohon II telah dilaksanakan sesuai dengan agama Islam.

Sejalan dengan analisis penulis bahwa pertimbangan hakim diatas memandang penting fakta yang diperoleh dari keterangan saksi, hal ini berarti yang bersifat menentukan pada produk putusan hakim adalah fakta konkrit. Adapun hal lain yang tidak dipertimbangkan dalam pertimbangan hukum putusan hakim Pengadilan Agama Bandung Nomor Perkara 202/Pdt.P/2019/PA.Badg adalah petitum permohonan angka 3 yaitu:

"Bahwa dari pernikahan tersebut telah dikaruniai 1 (satu) orang anak laki-laki bernama M.R.S yang lahir tanggal 04 Mei 2017"

Hal ini berarti anak yang lahir dari perkawinan yang sah secara materil saja (pernikahan yang sah menurut agama/kepercayaan tanpa ada pencatatan), atau perkawinan yang mengikuti prosedur Pasal 2 ayat (1) Undang-Undang Nomor 1 Tahun 1974 saja dapat memiliki hubungan keperdataan dengan ibu dan keluarga dari ibunya. Tentang anak yang lahir dari perkawinan tanpa ada pencatatan yang sah sejak dari dahulu hingga sekarang masih menjadi perbincangan dalam forum diskusi hukum. Pasalnya tidak ada peraturan yang baku untuk mengatur secara khusus mengenai hal anak yang lahir dari pernikahan siri, padahal dalam Pasal 43 ayat (1) Undang-Undang No. 1 Thn 1974 menyatakan bahwa kedudukan anak yang lahir dari perkawinan tanpa ada pencatatan yang sah akan diatur dalam Peraturan Pemerintah, namun hingga kini peraturan dimaksud tidak pernah diterbitkan.

Meskipun ada yurisprudensi putusan MK Nomor 46/PUU-VIII/2010, yang memberikan pencerahan mengenai hubungan keperdataan/nasab bagi anak dari perkawinan tanpa ada pencatatan yang sah, yaitu mempunyai hubungan perdata dengan ibunya dan keluarga ibunya serta dengan laki-laki sebagai ayahnya yang dapat dibuktikan berdasarkan ilmu pengetahuan dan teknologi dan/atau alat bukti lain menurut hukum mempunyai hubungan darah (Anonimus, 2010), namun dalam putusan itu tidak dijelaskan bagaimana cara melakukan pembuktian dimaksud dan melalui "Lembaga" apa pemeriksaan itu dilaksanakan. 
Dalam Buku II Revisi Tahun 2010 Pedoman Pelaksanaan Tugas Dan Administrasi Pengadilan disebutkan bahwa pengakuan anak dapat diajukan secara voluntair yaitu adanya permohonan dari ibu kandung si anak agar anak kandungnya itu dinasabkan kepada laki-laki yang menurut pengakuannya adalah ayah biologisnya. Jika hal ini terjadi, maka tata cara pengajuan permohonan penetapan asal usul anak ini bersifat voluntair, yaitu pihak yang berkepentingan sebagai subjek hukum mengajukan permohonan ke Pengadilan Agama dalam wilayah hukum di mana anak atau wali anak tersebut bertempat tinggal (Mahkamah Agung RI Dirjend Badilag, 2011). ${ }^{12}$ Tentunya permohonan tersebut harus memenuhi ketentuan syarat formil gugatan/permohonan, yakni adanya identitas, fundamentum petendi/posita dan petitum. Biasanya dalam perkara yang bersifat voluntair yang mengajukan adalah seorang laki-laki sebagai Pemohon I yang mengaku dirinya memiliki hubungan nasab dengan anak yang diakuinya, dan seorang perempuan sebagai Pemohon II yang mengaku ibu kandungnya.

Penulis meyakini bahwa dengan alasan tersebut majelis hakim mengesampingkan petitum permohonan angka 3 maka perkara itsbat nikah tidak digabungkan dengan perkara asal-usul anak, karena tidak menjadi bagian perkara yang sama melainkan dibedakan antara itsbat nikah dan asal-usul anak.

Dari sini kita dapat melihat bahwa hakim dalam memutus perkara tidak main-main mengaplikasikan suatu peraturan dan norma kedalam satu putusan, sebagaimana yang sudah dijelaskan diatas tugas pokok hakim adalah menerima, memeriksa dan mengadili serta menyelesaikan perkara yang diajukan. Dalam memeriksa dan mengadili suatu perkara banyak komponen yang diformulasikan hakim dalam menyelesaikan suatu perkara seperti peraturan mana yang relevan untuk diterapkan kedalam putusan hakim, melihat fakta saat proses pemeriksaan diruang sidang, hingga menimbang dengan melihat dari berbagai sudut pandang seperti kepada yurisprudensi hingga akhirnya hakim melakukan ijtihad dengan mengistinbath, istinbath adalah suatu proses penemuan hukum untuk menetapkan hukum ketika ada pertentangan satu dalil dengan dalil lainnya ${ }^{13}$ (Nurul Hakim, 2014).

Pada intinya penulis mendorong pekerja hukum yang memiliki gagasan hukum progresif untuk berani membuat terobosan dalam menjalankan hukum di Indonesia dan tidak hanya dibelenggu oleh pikiran positivistis dan legal analytical. Terobosan tersebut bukan berarti anarki, karena masih banyak jalan, metode hukum, teori hukum serta paradigma baru yang dapat diajukan untuk menyelesaikan perkara. Paradigma hukum progresif yang digagas sang begawan hukum Satjipto Rahardjo dalam bukunya, Negara Hukum Yang Membahagiakan Rakyatnya, menyampaikan sebuah gagasan yang fenomenal yang ditujukan kepada aparatur penegak hukum terutama kepada sang Hakim

\footnotetext{
12 Mahkamah Agung RI Dirjend Badilag, Buku I/ Revisi Tahun 2010 Pedoman Pelakasanaan Tugas Dan Administrasi Pengadilan, (Jakarta: Mahkamah Agung, 2011), hlm. 35-36.

13 Nurul Hakim, Kumpulan Jurnal Dosen Unsu, Eksistensi 'Illat Sebagai Sarana Dalam Istinbath Hukum, Kumpulan Jurnal Dosen. Vol. 7 No. 1 Tahun 2014.
} 
agar pemikiran hakim jangan terbelenggu dengan positivisme hukum yang selama ini banyak memberikan ketidakadilan kepada yustisiaben (pencari keadilan) dalam menegakkan hukum karena penegakan hukum merupakan rangkaian proses untuk menjabarkan nilai, ide, cita yang cukup abstrak yang menjadi tujuan hokum. ${ }^{14}$

Soerjono Soekanto mengatakan secara konsepsional inti dari arti penegakan hukum terletak pada kegiatan menyerasikan hubungan nilai-nilai yang terjabarkan di dalam kaidah-kaidah yang mantap dan mengejewantah sikap tindak sebagai rangkaian penjabaran nilai tahap akhir, untuk menciptakan, memelihara dan mempertahankan kedamaian pergaulan hidup (Satjipto Rahardjo, 2009). ${ }^{15}$ Hakim sebagai petugas keadilan, jika ada Hakim yang terbelenggu dan harus patuh kepada peraturan setingkat Sema maka negara itu adalah negara otoriter karena undang-undang itu dibuat oleh pejabat yang berwenang dan putusan hakimnya mengacu kepada perintah tersebut, ini berarti memberi kesan bahwa putusan hakim itu dibawah perintah. Jika putusan hakim seperti hal tersebut maka hilang jati diri hakim sebagi petugas keadilan karena sudah mengganggu independsi hakim. Dampaknya para hakim tidak terbebas dari pengaruh dan mendapat tekanan dari lingkungannya sehingga dalam mengadili suatu perkara hakim bisa salah mengimplementasikan hukum dalam putusannya tidak sesuai berdasarkan fakta yang terbukti dipengadilan.

Al-Qurán menetapkan bahwa hak laki-laki mendapat dua bagian dan hak perempuan mendapat satu bagian, hal itu bisa saja berubah oleh hakim dengan keilmuannya dalam hal kepentingan sesuai fakta dilapangan dan dalam hal keadilan, karena itu di dunia akademik/tataran normatif sebuah aturan itu adalah normanya, namun keadilannya yang seperti apa? hakim diperbolehkan untuk berijtihad. Dapat disebutkan bahwa Al-Qurán itu sebagai tataran norma dan didalam mencari keadilan hakim bisa mencari dengan jalan berijtihad. Independensi hakim sebagai norma dimana para hakim bebas dari pengaruh apalagi tekanan lingkungannya dan mengadili suatu perkara hanya berdasarkan fakta yang terbukti di pengadilan dan berdasarkan hukum.

Setiap putusan Hakim wajib mencantumkan irah-irah "Demi Keadilan Berdasarkan Ketuhanan Yang Maha Esa" sesuai Pasal 2 Ayat 1 UU No. 48 tahun 2009 tentang PokokPokok Kekuasaan Kehakiman. Maka Tanpa irah-irah tersebut, putusan hakim tak punya nilai apa-apa (non-executable). Artinya, hakim dalam mengemban amanatnya, tidak sekedar bertanggungjawab kepada hukum dan pada dirinya sendiri atau kepada pencari keadilan, tetapi juga mutlak harus bertanggungjawab kepada Tuhan Sang Pencipta dan pemilik hukum. Hakim hakikatnya hanyalah kepanjang-tanganan Tuhan, untuk menetapkan sebuah hukum (Has23).

14 Satjipto Rahardjo, Negara Hukum Yang Membahagiakan Rakyatnya, (Yogyakarta: Genta Publishing, 2009), hlm. 67.

15 Ibid. 
Hakim adalah profesi yang mulia (officium nobile) di sisi lain hakim adalah profesi yang sangat beresiko, hanya hakim yang berhak mendapat gelar "Yang Mulia". Tidak ada pejabat lain yang berhak, bahkan presiden sekalipun. Penulis berpendapat, karena beresikonya profesi hakim ini, Nabi Muhammad SAW menegaskan ada tiga tipikal hakim dan dari ketiganya dua masuk neraka dan hanya satu yang masuk surga. Hakim yang masuk surga adalah hakim yang mengetahui kebenaran, serta memutus dengan kebenaran. Sedangkan dua tipe hakim tersisa, yaitu hakim yang mengetahui kebenaran, namun tidak memutus dengan kebenaran dan hakim yang tidak mengetahui kebenaran dan memutus dengan ketidak benaran itu, maka nerakalah yang siap melahap mereka.

Tidak semata-mata pikiran hakim yang liar untuk berijtihad akan tetapi tetap mengacu kepada keadilan berdasarkan konstruksi pemikiran yang berkeadilan demi Ketuhanan Yang Maha Esa didasari keilmuan yang menunjang untuk berijtihad dan sudah diupayakan oleh hakim dalam putusan itu. Gagasan tersebut diperkuat dengan pernyataan Abdul Somad Batubara atau lebih dikenal dengan Ustadz Abdul Somad saat menyampaikan ceramahnya pada undangan dari Mahkamah Agung Republik Indonesia dirinya menyampaikan yang paling mulia diantara hakim itu adalah Allah SWT, sesuai firman-Nya:

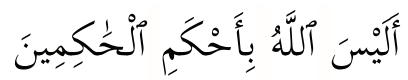

"Bukankah Allah Hakim yang seadil-adilnya?" (QS. at-Tin: 8)

Hakim di dunia dibagi kepada tiga bagian, yaitu hakim yang menghukum tanpa ilmu pengetahuan, yang kedua adalah hakim yang menghukum dengan ilmu pengetahuan tapi tidak disertakan ilmu pengetahuannya karena terdorong oleh hawa nafsunya, dan yang ketiga hakim yang menghukum dengan ilmu pengetahuan di implementasikannya syariat Tuhan.

Jadi suatu aturan jangan dijadikan aturan utama, hakim bukanlah petugas undangundang, ketika keadilan itu tidak persis bersenyawa dengan undang-undang maka hakim harus bekerja. Jadi Hakim itu bekerja demi keadilan berdasarkan Ketuhanan Yang Maha Esa. Kemanfaatan, kepastian hukum, dan keadilan itu cita-cita Hakim membuat putusan, peraturan itu sebagai alat Hakim dan itu dibutuhkan disaat ada peristiwa yang disidangkan oleh Hakim dan itu bersesuaian dengan undang-undangnya maka aturan itu kita masukan sebagai bagian dari pertimbangan hukum. Jika peraturannya tidak tepat diterapkan dalam putusan itu maka kita berijtihad. Hakim harus berijtihad maka Hakim masuk surga, cara kerja hakim itu karena keringatnya dan bukan karena ada peraturan yang hanya sedikit-sedikit atau tipis-tipis cocok untuk diterapkan.

\section{KESIMPULAN}

SEMA berkedudukan di bawah undang-undang, bukan setara atau lebih tinggi dari undang-undang. SEMA hanya mengikat ke dalam lingkungan peradilan saja, sedangkan undang-undang adalah suatu peraturan hukum tertinggi di bawah Undang-Undang Dasar 
Negara Republik Indonesia Tahun 1945 (UUD 1945) serta berkekuatan mengikat terhadap seluruh warga negara Indonesia. Secara normatif hukum walaupun SEMA dibuat oleh atasan dari para hakim dalam hal ini Ketua Mahkamah Agung tidak menjadi keharusan hakim terbelenggu dan terpaku pada SEMA melainkan hakim boleh mengesampingkan SEMA. Hakim bisa contra legem (mengesampingkan) peraturan bila menurut hakim bunyi dari peraturan Sema itu tidak relevan untuk di terapkan dalam putusannya, situasi ini yang bersifat menentukan pada produk putusan hakim (fakta konkret).

\section{Daftar Pustaka}

(n.d.). Undang-Undang No.48 Tahun 2009 tentang kekuasaan Kehakiman.

Anonimus. 2010. Putusan Mahkamah Konstitusi Nomor Nomor 46/PUU-VIII/2010 tanggal 17 Februari.

Hakim, Nurul. 2014. Kumpulan Jurnal Dosen Unsu, Eksistensi 'Illat Sebagai Sarana Dalam Istinbath Hukum. Kumpulan Jurnal Dosen. Vol 7. Sumatera: 154.

Harahap, Yahya. 2016. Hukum Acara Perdata tentang Gugatan, Persidangan, Penyitaan, Pembuktian dan Putusan Pengadilan. Jakarta: Sinar Grafika.

Henry P., Panggabean. 2001. Fungsi Mahkamah Agung dalam Praktik Sehari-Hari. Jakarta: Sinar Harapan.

Lubis, Sulaikin. 2006. Hukum Acara Perdata Peradilan Agama di Indonesia. Jakarta: Kencana.

M. F., Soeprapto. 1998. Ilmu Perundang-Undangan: Dasar-Dasar Pembentukannya. Yogyakarta: Kanisius.

Mahkamah Agung RI Dirjend Badilag. 2011. Buku // Revisi Tahun 2010 Pedoman Pelakasanaan Tugas Dan Administrasi Pengadilan.

Rahardjo, Satjipto. 2009. Negara Hukum yang Membahagiakan Rakyatnya. Yogyakarta: Genta Publishing.

Rosyadi, Aden. 2015. Peradilan Agama di Indonesia. Bandung: Simbiosa Rekatama Media.

SEMA Nomor 3 Tahun 2018. 2018. Tentang Pemberlakuan Rumusan Hasil Rapat Pleno Kamar Mahkamah Agung Tahun 2018 Sebagai Pedoman Pelaksanaan Tugas Bagi Pengadilan. Jakarta: Mahkamah Agung.

Soejono, Soekanto. 2005. Pengantar Penelitian Hukum. Jakarta: UI-PRESS.

Sunario. 2021. Hasil webinar tentang Pembinaan Teknis Peradilan Agama Virtual: Batas Kewenangan Mahkamah Agung dan Komisi Yudisial dalam Mengawasi Hakim.

Webinar. 2021. Tentang Pembinaan Teknis Peradilan Agama Virtual: Batas Kewenangan Mahkamah Agung dan Komisi Yudisial dalam Mengawasi Hakim.

Zamzami, Mukhtar. 2013. Perempuan dan Keadilan Dalam Hukum Kewarisan Indonesia. Jakarta: Prenada Media. 